British Journal of Marketing Studies (BJMS)

Vol. 8, Issue 1, pp.29-46, February 2020

Published by ECRTD- UK

Print ISSN: 2053-4043(Print), Online ISSN: 2053-4051(Online)

\title{
GAP ANALYSIS OF CUSTOMER EXPECTATION AND PERCEPTION OF PROFESSIONALISM AMONG NIGERIA POLICE OFFICERS: THE SERVICOM PERSPECTIVE
}

\author{
*OLOWE, Temitope Sunday ${ }^{1}$ and OGUNODE, Philips Olatunde ${ }^{2}$ \\ Department of Marketing, School of Business, Federal Polytechnic, PMB 5351, Ado-Ekiti, \\ Ekiti State, Nigeria \\ *Corresponding author: olotemitope@gmail.com; +2348032196955
}

\begin{abstract}
This paper investigated gap analysis of customer expectation and perception of professionalism among Nigeria police officers: the SERVICOM perspective. The study specifically examined the effect of SERVICOM on professionalism of service as well as gap between customer expectation and perception of Nigeria police service. Descriptive survey design was adopted through which structured questionnaire was used to collect data from the field. The population of the study comprised of all police officers from all ranks and files within Ekiti and Ondo States as well as consumers of police services. Convenience sampling technique was used to select 4,000 respondents which included 2,000 police officers from different ranks and files as well as 2,000 consumers of police services within the two states. Descriptive statistics was used to analyze the research questions while t-test and Chi-square $\left({ }_{x}^{2}\right)$ were used to test hypothesis one and two respectively. The level of significance was set at 5\%. Findings revealed that there was significant difference between customers' expectation and perception regarding the quality of service provided by the Nigeria Police Force. It was therefore recommended among others that Regulatory authorities in the Nigerian Police Force should take steps to ensure that the operations of the Force are, to some extent, consistent with the expectations of customers as this will help to minimize the discrepancies between customers' expectation of services and the actual service realized from the Force.
\end{abstract}

KEYWORDS: Nigeria police, SERVICOM, professionalism, awareness, tangibility, reliability

\section{INTRODUCTION}

Service compact (SERVICOM) is an administrative tool to drive the Federal Government's service delivery initiative that will ensure quality service. Government business in Nigeria had almost become no one's business and this has adversely affected the level of satisfaction that members of the public derive from public service. The service provided by the Nigeria Police Force is not an exception and it was consequent upon this that SERVICOM was established to perform the following functions:

(i) Establish and maintain SERVICOM desks at all police commands and formations by having officers trained in SERVICOM and deployed to the field who will treat issues related to service failure on the part of police formations handling Criminal cases etc;

(ii) Draw up the Nigeria Police Force Charter, implement it and make periodic review of same to 
Print ISSN: 2053-4043(Print), Online ISSN: 2053-4051(Online)

meet contemporary issues;

(iii) Organize periodic training and workshop to keep officers current at all times of the customer relations/grievance redress mechanism;

(iv) Investigate complaints from members of the public on service failure and make appropriate recommendations and where any member of the public is not satisfied with police performance in the area of investigation, such complaint is brought to the police authority for prompt action;

(v) Maintain routine inspection of SERVICOM desks of the force to ensure that they remain functional and productive all the time.

Since its introduction, SERVICOM has significantly improved the way and manner in which government work is being carried in Ministries, Parastatals and Agencies. For example, in a study by Emejulu, Muo and Chukwuemeka (2014) on the effect of SERVICOM on service delivery in Nnamdi Azikiwe University Teaching Hospital, Nnewi; it was revealed that the introduction of SERVICOM has improved service delivery and has led to clients' turnover rate in a one-time deserted government hospital. This study was carried to examine the effect SERVICOM on professionalism and the gap between customer expectation and perception of service delivered by the NPF.

\section{Statement of the Problem}

The current situation of the Nigeria Police Force and the attendant implications it has on the image of the country is the major motivation for this study. According to the Global Security Watch (1983), the Nigeria Police is rated very low in terms of professionalism. Increasing cases of indecent dressing, harassment of Motorists, improper handling of weapons, smoking on duties and the likes seem to be a re-occurring incidence among the Nigeria Police (Osayande, 2008).

In like manner, poor service delivery, poor attitude to work, corruption, dishonesty and bureaucratic bottlenecks seem to have combined to widen the gap between customers' expectations and perception of service delivered by the Nigeria Police Force. According to Osayande (2008), good service delivery is an imperative and panacea to bridging the gap between customer expectation and perception but cases of human right violation, corruption, dishonesty and delay in providing quality services have significantly cut short these expectations.

From the perspective of the principles of public administration, it could be deciphered that these short comings bothered mainly on the management of both the materials and human resources meant to direct resources of the Nigeria Police Force towards the satisfaction of the citizens.

Despite the efforts of both past and present administrations in ensuring professionalism and enhancing public confidence in the Nigeria Police Force, it would appear that these efforts are not yielding dividends as the introduction of SERVICOM has not really bridged the gap between customer's expectation and the actual service received from the Nigeria Police Force. These are the critical issues that provoked this study.

\section{Objectives of the study}

The general objective of the study is to examine how the introduction of SERVICOM has enhanced 
service delivery in the Nigeria police force. The specific objectives of the study are to:

i. Examine the effect of professionalism of service on the Nigeria police force service delivery.

ii. Find out the gap(s) that exist between customers' expectations and perceptions regarding the quality of service provided by the Nigeria police force

\section{LITERATURE REVIEW}

\section{Conceptual Review}

\section{The Concept of Professionalism}

As Freidson (1994) suggested, 'much of the debate about professionalism is clouded by unstated assumptions and inconsistent and incomplete usages. Indeed, Hargreaves and Goodson (1996) refer to the lack of consensus relating to the meaning of professionalism. Fox (1992) makes the same obvious point; 'Professionalism means different things to different people and it is unlikely that the term professionalism will be used in only one concrete way. Englund (1996) similarly referred to the lack of conceptual clarity and consensus relating to 'teaching as a profession'. Hoyle (1975) explained professionalism as 'those strategies and rhetoric employed by members of an occupation in seeking to improve status, salary and conditions. More recent interpretations of professionalism incorporate recognition of the transposition within the political arena of public sector professions. In relation to locus of control, Hoyle's interpretation, while it lies within the parameters of it, is distinct from that of Ozga (1995) who analysed the concept of professionalism as a form of occupational control of teachers. 'Professionalism is best understood in context, and particularly in policy context. Critical analyses of professionalism do not stress the qualities inherent in an occupation but explore the value of the service offered by the members of that occupation to those in power.

Troman (1996) similarly perceived professionalism not as an absolute or an ideal, but as 'a socially constructed, contextually variable and contested concept. It is defined by management and expressed in its expectations of workers and the stipulation of tasks they will perform. Congruent with this are Gleeson et al. (2005) highlighting of contextual relevance to conceptualization, and Holroyd's (2000) interpretation; "professionalism is not some social-scientific absolute, but a historically changing and socially constructed concept-in-use", a point both illustrated by Evetts (2006)'s examination of the changing nature of discourse of professionalism and supported by Helsby (1999) in relation to teacher professionalism: 'there is nothing simple or static about the concept of teacher professionalism in service delivery, it is constantly changing and constantly being redefined in different ways and at different times to serve different interest'.

Hoyle (2011) defined professionalism as a term used to describe enhancement of the quality of service' some to align more closely with these inclusion of new professionalisms interpretations than the one employed over thirty years ago. Sockett (1996) followed the same 'quality' line 'Professionalism is about the quality of practice 'and the public status of the job', though Hoyle questions the inclusion of status as a dimension of new professionalism; sometimes intentionally, 
but more often unintentionally, 'professionalism' has the same connotation in the phrase 'the new professionalism' as that adopted in this article, that is , improvement in the quality of service rather than the enhancement of status'

Many interpretations, perhaps representing a broad consensus, seem to focus on professionalism's being an externally imposed, articulated perception of what lies within the parameters of a profession's collective remit and responsibilities. In setting the positions of these parameters- and, hence, in defining the boundaries of the profession's actual and potential authority, power and influence-external agencies appear to have the capacity for designing and delineating professions. In one sense, then, professionalism may be interpreted as what is effective representation of a service level agreement, imposed from above.

Yet some interpretations lie outside this broad consensual one. Boyt, et al. (2001) argued that 'Professionalism consists of the attitudes and behaviour one possesses toward one's profession. It is an attitudinal and behavioural orientation that individuals possess toward their occupations. Helsby (1995) made the same point about teacher professionalism: 'If the notion of "professionalism" is socially constructed, then teachers are potentially key players in that construction, accepting or resisting external control and asserting or denying their autonomy.' A common feature of many conceptions of new professionalism in the Nigeria Police Force context is a focus on practitioner control and proactively. Hargreaves and Goodson's (1996) as well as Sachs' (1999) adopted principles of teacher professionalism which incorporate a focus on teachers' taking greater responsibility for defining the nature and content of their work. This, in part, is consistent with Freidson's (1994) interpretation of professionalism. In this study, professionalism is referred to as an occupation that controls its own work, organized by a special set of institutions sustained in part by a particular ideology of expertise and service. It is used to refer to that ideology and special set of institutions.

\section{Historical Background of the Nigerian Police Force}

Like any other structure or institution, the Nigerian Police Force has a history. Its history in Nigeria particularly dated back to 1861 during colonial era, when the consul of Lagos colony established a consular guard of thirty members to watch over the colonial properties. This guard grew in size and was later known as the Hausa constabulary. This was because it was dominated by Northerners. In 1896 the Lagos police was established. A similar force was already formed in Calabar in 1894 known as the Niger Cost Constabulary. And in the North too, the Royal Niger Company set up Royal Niger Company Constabulary in 1888. In the early 1900's when the protectorates of Northern and Southern Nigeria were proclaimed, part of the Royal Niger Company constabulary became the Northern Nigeria Police and part of Nigeria Coast Constabulary became the Southern Nigeria Police. Although the South and North were amalgamated in 1914, their police forces were not merged until in 1930, with headquarters in Lagos.

It is important to also note that during colonial period, most police were associated with local government (Native authorities). But by 1960's under the first Republic, these forces were regionalized and then nationalized. By this Nationalization of the Nigeria Police Force, the 
Print ISSN: 2053-4043(Print), Online ISSN: 2053-4051(Online)

Inspector General of Police was in control of the general operation and administrative duties. He was supported at the headquarters by a deputy Inspector General and in each state by Police Commissioners. The 1999 constitution also provided for a Police Service Commission that is today responsible for Policy, organization, administration and finance of the Nigerian police force (Alemika, 1998). .

\section{The Roles of Nigerian Police Force}

Traditionally, policing was the responsibility of all adults in community. In medieval society, all male adults were obliged to contribute towards the prevention and control of crime and disorder under the system "hue, cry and pursuit". But the emergence of the state, with its vast bureaucracies anchored on centralization, hierarchical authority/power structure, and professionalism changed the traditional policing method of policing being every one's business (Weber, 1968). The emergence of an entity with its claim to the monopoly over the means of legitimate violence in society resulted into the creation of specialized agencies such as police and the Armed Forces charged with the responsibility of controlling the use of violence by other groups. By this therefore police was scheduled to perform the following responsibilities or duties:

i. Prevention of crime

ii. Protection of lives and properties

iii. Enforcing law

iv. Maintenance of peace and public order.

v. Providing a wide range of services to the citizens.

By doing this, it has the potential for violence and right to use coercive means in order to establish social control (Adebayo and Ojo, 2009).

According to Yecho (2004), the Nigeria Police is statutorily required to fight crime through detection, investigation, apprehension and prosecution of offenders in law court and the protection of lives and property through proactive policing. To Tinubu (1993), the place of police in Nigeria cannot be compromised. Their constitutional and statutory functions according to him are well defined so that the force can manage crisis situation, maintain peace and security.

The Nigerian government has acknowledged the problems militating against effective performance of the Nigeria Police Force as postulated above. In contemporary times therefore, it appears there are growing efforts in ensuring the efficiency and effectiveness of the Police Force towards the maintenance of peace and security in Nigeria. For example, from the late 1990's to date, the Nigerian Police Force has embarked on several measures of fighting crime some of which includes: Operation Sweep, Operation Flush, Operation Fire for Fire, Anti-crime Patrol, Operation Dzenda to mention a few have been introduced. All these are efforts to ensure peace. However, it can be argued that these measures have not been able to attain the desired aims and objectives. This calls for a critical examination of the roles of the Nigerian Police Force in order to assess its efficiency, effectiveness and service delivery towards peace and order in the society. The aim is to understand what contributions each of these measures have made towards ensuring peace and security. Some of these measures are: 


\section{The Role to Serve and Protect with Integrity Programme}

The removal of Tafa Balogun as Inspector General of Police marked the death of "Operation Fire for Fire" and in its place a new concept of fighting crime control known as "serve and to protect with integrity" was introduced. This programme was not only meant to fight crime but also to redeem the battered image of the Police Force. It was formally launched as the Nigeria Police Force Action Programme that should form a guiding principle of the Police Force in discharging their duties. As stated by the 10-point programme of action in 2005, the programme had plan of action that touches on all the nooks and cranny of Nigerian security from types of social disorder to the composition of police personnel down to the social relations with the public. It was aimed at effective crime control through intelligence led policing, conflict prevention and resolution, community policing and police partnership, zero tolerance for police corruption and indiscipline among others.

The programme, never the less, uplifted the working condition of the Police Force as their take home pay was increased and paid promptly too. Recruitment and promotion of personnel was no longer cumbersome and frustrating as it used to be and the people (both public and police officers) started appreciating the institution as compared to what used to be. In spite of these achievements, the programme could not manage crime and insecurity in the country rather this period witnessed the highest level of crime and instability. Armed robbery became a royal carrier and People took pleasure in advance fee fraud (419). Cult activities also heightened because they were not confronted by the police any longer. In Benue State for instance Operation Dzenda which is a joint security team comprising of the Army, Civil Defence and the Police Force aimed at combating crime and ensuring security most especially in the rural areas. Cars are distributed to them and logistics put in place in every local government area in the state. This team is doing much by combating crime and cultism. But at the same time, some politicians are using them to fight opposition particularly those in executive positions.

Also, rather than routine patrol in border and rural areas, they tend to mount road blocks on roads extorting money from the public particularly on market days. This act has affected their performance greatly and to some extent the aim of the programme itself. Going by this inconsistency of the Nigeria Police Force in combating crime and ensuring security of lives and property, one is left with nothing but doubts as to what will happen next in the mist of ethnoreligious crisis, illegal possession of fire arms, poverty and unemployment and political thuggery. Indeed, the security of lives and properties of Nigerians is up till now at the mercy of God (Balogun, 2002).

\section{SERVICOM and Its Roles in the Nigeria Police Force}

SERVICOM, an acronym of the words service compact is an administrative tool to drive the Federal Government's service delivery initiative that will ensure quality service. In this regard, the section performs the following functions:

(i) Establish and maintain SERVICOM desks at all police commands and formations by having officers trained in SERVICOM and deployed to the field. They are to treat issues related to service 
Print ISSN: 2053-4043(Print), Online ISSN: 2053-4051(Online)

failure on the part of police formations handling Criminal cases etc.

(ii) Draw up the Nigeria Police Force Charter, implement it and make periodic review of same to meet contemporary issues. A chatter is formal written statement describing the rights and responsibilities of a state and its citizens.

(iii) Organize periodic training and workshop to keep officers current at all times of the customer relations/grievance redress mechanism.

(iv) Investigate complaints from members of the public on service failure and make appropriate recommendations. Where any member of the public is not satisfied with police performance in the area of investigation, or any service not well delivered, and such complaint is brought the police authority, it behooves on the officer in-charge of SERVICOM when such issue is referred to him to investigate and make appropriate recommendation that will within the ambit of the Law assuage the feelings of such members of the public.

(v) Maintain routine inspection of SERVICOM desks of the force to ensure that they remain functional and productive all the time.

\section{METHODOLOGY}

\section{Research Design}

Survey design was adopted because it gives the researcher the opportunity to sample different opinions and obtain current information from the sampled respondents on the subject matter. The population of the study was made up of all the Police Officers across the ranks and files in Ondo and Ekiti states of Nigeria. In addition, the Nigeria citizens who are the recipients of the services within the two states also took part in the study. Convenience sampling (a form of non-probability sampling) was used to select 1000 police officers across the ranks and files in each of the States. The Researcher administered questionnaire to Police Officers on duty in each of the divisional police headquarters in the two states. By implication, 2000 men of the force took part in the study. Furthermore, quota sampling technique was adopted in selecting the respondents who received questionnaire. This technique became inevitable because it allowed all the officers across ranks and files as well as both gender the opportunity to participate in the study.

Convenience sampling was also used to select 1000 consumer respondents from the two states that were used for the study. In all, 2000 consumer respondents were selected. Total sample size in this case was 4000. Data were collected at some selected Police stations with due permission from Commissioners of Police in the two states selected for this study. Police check points within the two states were also visited in the course of data collection. Consumer respondents in the study were majorly the clients who have case(s) with the Police as well as motorists at different Police check points as at the time of investigation.

Questionnaire and interview were used to collect data from 2000 Police Officers and 2000 consumers of Police services who participated in the study. Furthermore, interview was conducted for the illiterates among the consumers of the services provided by the Nigerian Police Force. The questions included those on personal background of the respondents, that is, age, gender, academic qualification and sex while the other questions were drawn from the core subject matter of the 
British Journal of Marketing Studies (BJMS)

Vol. 8, Issue 1, pp.29-46, February 2020

Published by ECRTD- UK

Print ISSN: 2053-4043(Print), Online ISSN: 2053-4051(Online)

research investigation. The data obtained in this study was compiled and analyzed descriptively using Ms Excel (Microsoft corp. USA) and Statistical Package for Social Sciences (SPSS version 20.0) data analyzing software. Descriptive statistics was used to analyze the research questions while t-test and Chi-square $\left(\chi^{2}\right)$ were used to test hypotheses one and two respectively. The level of significance chosen was $5 \%$.

\section{RESULTS AND DISCUSSION}

Four thousand (4000) questionnaires and the entire questionnaire were retrieved on the spot to ensure $100.0 \%$ returns, with all being good and usable for data analysis. The data were processed and analyzed using the Statistical Package for Social Sciences (SPSS) 23.0 version. The results are presented below.

Data Presentation

Demographic characteristic of Respondents

Table 01: Distribution of respondents by Gender

\begin{tabular}{lllll}
\hline Gender & Frequency & Percent & Valid Percent & Cumulative Percent \\
\hline Male & 3348 & 83.7 & 83.7 & 83.7 \\
Female & 652 & 16.3 & 16.3 & 100.0 \\
Total & 4000 & 100.0 & 100.0 &
\end{tabular}

Source: Researcher's Field Survey, 2019

Table 01 shows that $83.7 \%$ of the total respondents which is equivalent to 3384 are male while $16.3 \%$ which is equivalent to 652 are female.

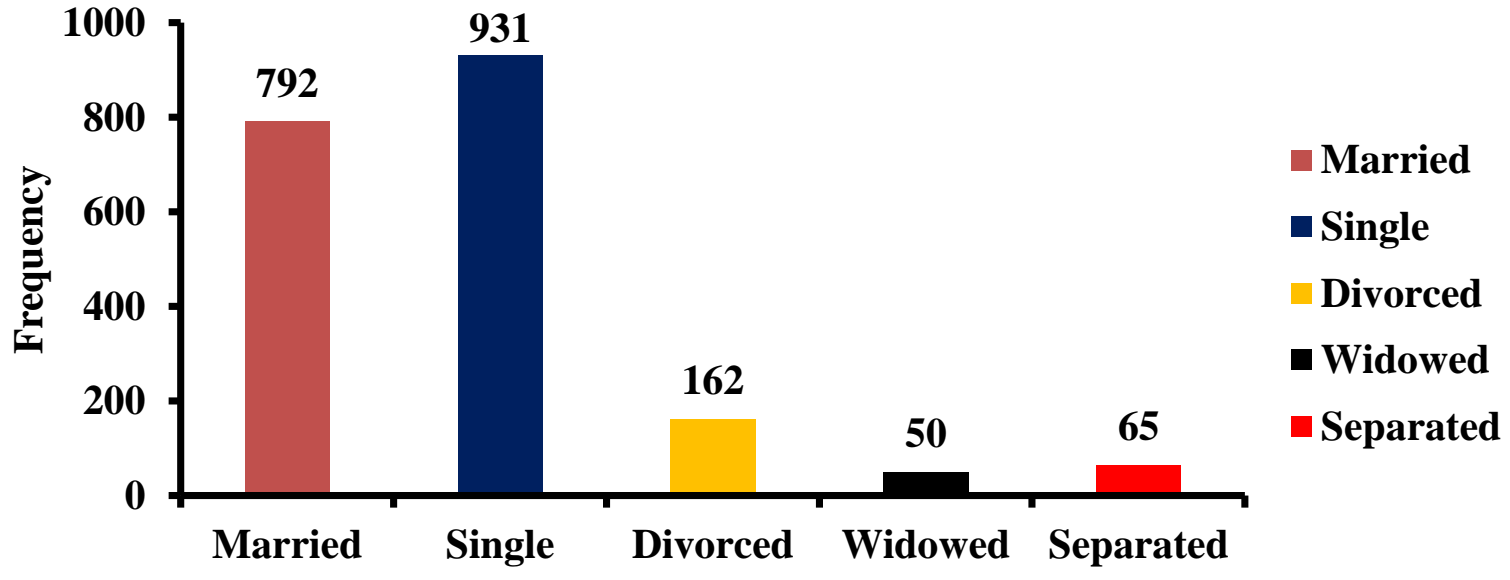

Figure 1: Distribution of Clients respondents by marital status

Figure 1 shows 792 (39.6\%) of the clients respondents are married, 931 (46.6\%) are single, 162 $(8.1 \%)$ are divorced while $50(2.5 \%)$ are widowed and $65(3.3 \%)$ are separated. 
British Journal of Marketing Studies (BJMS)

Vol. 8, Issue 1, pp.29-46, February 2020

Published by ECRTD- UK

Print ISSN: 2053-4043(Print), Online ISSN: 2053-4051(Online)

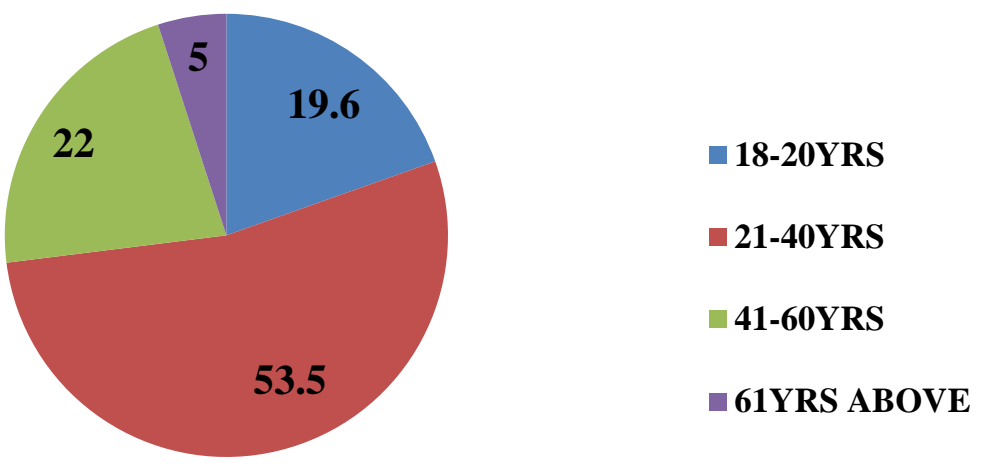

Figure 2: Distribution of clients respondents by age

Figure 2 reveals that $19.6 \%$ which is equivalent to 391 of the clients respondents are between the age of 18-20 years, 53.5\% (1070) are between 21-40 years while 22\% (439) are between 41- 60 years and 5\% (100) are 61years and above.

Table 02: Distribution of Respondents by Educational Qualification

\begin{tabular}{lllll}
\hline $\begin{array}{l}\text { Educational } \\
\text { Qualification }\end{array}$ & Frequency & Percent & Valid Percent & $\begin{array}{l}\text { Cumulative } \\
\text { Percent }\end{array}$ \\
\hline SSCE/NECO & 728 & 18.2 & 18.2 & 18.2 \\
ND/NCE & 1600 & 40.0 & 40.0 & 58.2 \\
HND/First Degree & 1362 & 34.1 & 34.1 & 92.3 \\
Master & 204 & 5.1 & 5.1 & 97.4 \\
Ph.D & 12 & .3 & .3 & 97.7 \\
Other & 94 & 2.4 & 2.4 & 100.0 \\
Total & 4000 & 100.0 & 100.0 & \\
\hline
\end{tabular}

Source: Researcher's Field Survey, 2019

The result in Table 02 reveals that $18.2 \%$ (1362) of the total respondents are SSCE/NECO holders, 40\%(1600) are ND/NCE holders, 34.1\%(681) are HND/First Degree while 204(5.1\%) are Master holders, $0.3 \%(12)$ are Ph.D holders and 94(2.4\%) have other education qualification. 
British Journal of Marketing Studies (BJMS)

Vol. 8, Issue 1, pp.29-46, February 2020

Published by ECRTD- UK

Print ISSN: 2053-4043(Print), Online ISSN: 2053-4051(Online)

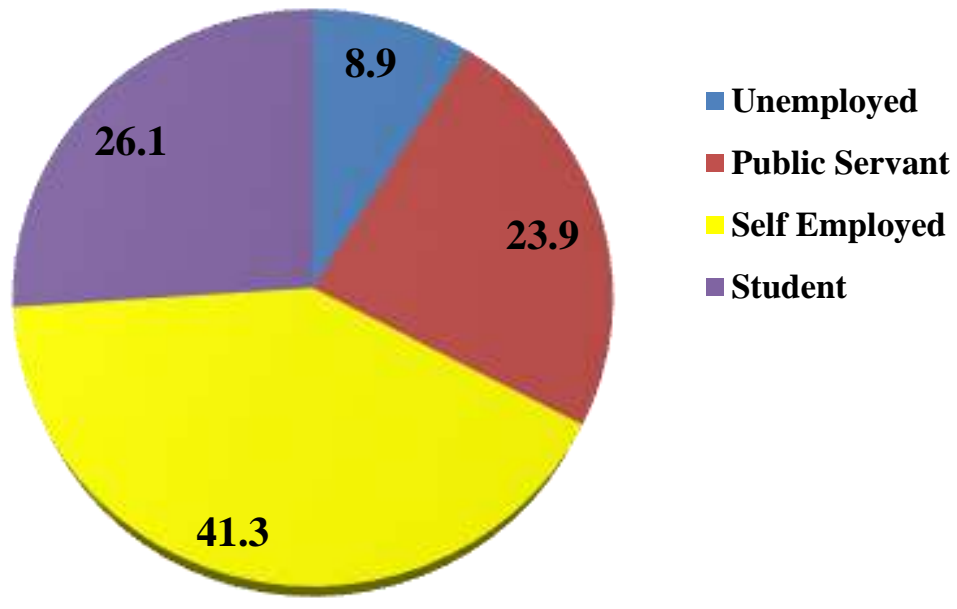

Figure 3: Distribution of Clients respondents by Occupation

The chart above indicates that $8.9 \%$ (177) are unemployed, 23.9\% (477) are public servant, while $41.3 \%$ (825) are self-employed and 26.1\% (521) are student.

Analysis of Research Questions

Table 03: Effect of Professionalism of Service on the Nigeria Police Force Service Delivery

\begin{tabular}{|c|c|c|c|c|c|c|}
\hline $\mathbf{S} / \mathbf{N}$ & ITEMS & SD & D & I & $\mathbf{A}$ & SA \\
\hline 1 & $\begin{array}{l}\text { The image of the Nigeria Police Force } \\
\text { has improved over the past five years }\end{array}$ & $\begin{array}{l}186 \\
(9.3 \%)\end{array}$ & $\begin{array}{l}888 \\
(44.4 \%)\end{array}$ & - & $\begin{array}{l}199 \\
(10 \%)\end{array}$ & $\begin{array}{l}727 \\
(36.4 \%)\end{array}$ \\
\hline 2 & $\begin{array}{l}\text { Police officers are proficient in handling } \\
\text { weapons and other operational gadgets. }\end{array}$ & $\begin{array}{l}282 \\
(14.1 \%)\end{array}$ & $\begin{array}{l}702 \\
(35.1 \%)\end{array}$ & - & $\begin{array}{l}345 \\
(17.3 \%)\end{array}$ & $\begin{array}{l}671 \\
(33.6 \%)\end{array}$ \\
\hline 3 & $\begin{array}{l}\text { Nigeria Police officers are civil enough } \\
\text { in their approach with clients. }\end{array}$ & $\begin{array}{l}298 \\
(14.9 \%)\end{array}$ & $\begin{array}{l}754 \\
(37.7 \%)\end{array}$ & - & $\begin{array}{l}355 \\
(17.8 \%)\end{array}$ & $\begin{array}{l}593 \\
(29.7 \%)\end{array}$ \\
\hline 4 & $\begin{array}{l}\text { Nigeria Police officers can be confided } \\
\text { in when sensitive matters are reported to } \\
\text { them }\end{array}$ & $\begin{array}{l}427 \\
(21.4 \%)\end{array}$ & $\begin{array}{l}725 \\
(36.3 \%)\end{array}$ & - & $\begin{array}{l}292 \\
(14.6 \%)\end{array}$ & $\begin{array}{l}556 \\
(27.8 \%)\end{array}$ \\
\hline 5 & $\begin{array}{l}\text { Nigeria Police officers are efficient in } \\
\text { intelligence gathering }\end{array}$ & $\begin{array}{l}255 \\
(12.8 \%)\end{array}$ & $\begin{array}{l}896 \\
(44.8 \%)\end{array}$ & - & $\begin{array}{l}278 \\
(13.9 \%)\end{array}$ & $\begin{array}{l}571 \\
(28.6 \%)\end{array}$ \\
\hline 6 & $\begin{array}{l}\text { Nigeria Police officers have the skills to } \\
\text { handle crisis before it goes out of hand }\end{array}$ & $\begin{array}{l}177 \\
(8.9 \%)\end{array}$ & $\begin{array}{l}786 \\
(39.3 \%)\end{array}$ & - & $\begin{array}{l}381 \\
(19.1 \%)\end{array}$ & $\begin{array}{l}656 \\
(32.8 \%)\end{array}$ \\
\hline 7 & $\begin{array}{l}\text { Nigeria Police officers can easily for- } \\
\text { see and prevent crime before it happen }\end{array}$ & $\begin{array}{l}493 \\
(24.7 \%)\end{array}$ & $\begin{array}{l}696 \\
(34.8 \%)\end{array}$ & - & $\begin{array}{l}167 \\
(8.4 \%)\end{array}$ & $\begin{array}{l}644 \\
(32.2 \%)\end{array}$ \\
\hline
\end{tabular}

Source: Researcher's Field Survey, 2019

Table 03 shows that $186(9.3 \%)$ strongly disagree that the image of the Nigeria Police Force has improved over the past five years, 888(44.4\%) disagreed while 199(10\%) agreed and 727(36.4\%) 
British Journal of Marketing Studies (BJMS)

Vol. 8, Issue 1, pp.29-46, February 2020

Published by ECRTD- UK

Print ISSN: 2053-4043(Print), Online ISSN: 2053-4051(Online)

strongly agreed. 282(14.1\%) strongly disagreed that police officers are proficient in handling weapons and other operational gadgets, 702(35.1\%) disagreed while 345(17.3\%) agreed and $671(33.6 \%)$ strongly agreed.

Similarly, 298(14.9\%) of the respondent strongly disagreed that Nigeria Police officers are civil enough in their approach with clients, 754(37.7\%) disagreed while 355(17.8\%) agreed and 593(29.7\%) strongly agreed. 427(21.4\%) strongly disagreed that Nigeria Police officers can be confided in when sensitive matters are reported to them, $725(36.3 \%)$ disagreed while $292(14.6 \%)$ agreed and 556(27.8\%) strongly agreed. 255(12.8\%) strongly disagreed Nigeria Police officers are efficient in intelligence gathering, 896(44.85) disagreed while 278(13.9\%) agreed and 571(28.6\%) strongly agreed. $177(8.9 \%)$ strongly disagreed that Nigeria Police officers have the skills to handle crisis before it goes out of hand, 786(39.3\%) disagreed while 381(19.1\%) agreed and 656(32.8\%) strongly agreed. 493(24.7\%) strongly disagreed that Nigeria Police officers can easily fore-see and prevent crime before it happens, 696(34.8\%) disagreed while 167(8.4\%) agreed and 644(32.2\%) strongly agreed. Concentration was on consumers of Police services for the purpose of objectivity of results

Table 04: Customers' expectation and perception of quality of service provided by the Nigeria Police force

\begin{tabular}{|c|c|c|c|c|c|c|}
\hline $\mathbf{S} / \mathbf{N}$ & ITEMS & SD & D & $\mathbf{I}$ & $\bar{A}$ & SA \\
\hline 1 & $\begin{array}{l}\text { Police station physical facilities (e.g. building and } \\
\text { furniture's) are virtually nice }\end{array}$ & $\begin{array}{l}275 \\
(13.8 \%)\end{array}$ & $\begin{array}{l}1118 \\
(55.9 \%)\end{array}$ & - & $\begin{array}{l}145 \\
(7.3 \%)\end{array}$ & $\begin{array}{l}462 \\
(23.1 \%)\end{array}$ \\
\hline 2 & Police are neatly appealing in their uniform & $\begin{array}{l}295 \\
(14.8 \%)\end{array}$ & $\begin{array}{l}729 \\
(36.5 \%)\end{array}$ & - & $\begin{array}{l}274 \\
(13.7 \%)\end{array}$ & $\begin{array}{l}702 \\
(35.1 \%)\end{array}$ \\
\hline 3 & Technology and equipment are up-to-date & $\begin{array}{l}392 \\
(19.6 \%)\end{array}$ & $\begin{array}{l}973 \\
(48.7 \%)\end{array}$ & - & $\begin{array}{l}291 \\
(14.6 \%)\end{array}$ & $\begin{array}{l}344 \\
(17.2 \%)\end{array}$ \\
\hline 4 & Police provide all the services as promised & $\begin{array}{l}368 \\
(18.4 \%)\end{array}$ & $\begin{array}{l}1174 \\
(58.7 \%)\end{array}$ & - & $\begin{array}{l}184 \\
(9.2 \%)\end{array}$ & $\begin{array}{l}274 \\
(13.7 \%)\end{array}$ \\
\hline 5 & Policemen operating hours are convenient to me & $\begin{array}{l}225 \\
(11.3 \%)\end{array}$ & $\begin{array}{l}981 \\
(49.1 \%)\end{array}$ & - & $\begin{array}{l}314 \\
(15.7 \%)\end{array}$ & $\begin{array}{l}480 \\
(24 \%)\end{array}$ \\
\hline 6 & $\begin{array}{l}\text { the Nigerian police force deliver error free and up to date } \\
\text { services }\end{array}$ & $\begin{array}{l}336 \\
(16.8 \%)\end{array}$ & $\begin{array}{l}818 \\
(40.9 \%)\end{array}$ & - & $\begin{array}{l}339 \\
(17 \%)\end{array}$ & $\begin{array}{l}507 \\
(25.4 \%)\end{array}$ \\
\hline 7 & Police are willing to help me wherever the need arise & $\begin{array}{l}171 \\
(8.6 \%)\end{array}$ & $\begin{array}{l}1090 \\
(54.5 \%)\end{array}$ & - & $\begin{array}{l}223 \\
(11.2 \%)\end{array}$ & $\begin{array}{l}516 \\
(25.6 \%)\end{array}$ \\
\hline 8 & $\begin{array}{l}\text { The Nigerian police force provide quick services in } \\
\text { solving client's problems }\end{array}$ & $\begin{array}{l}263 \\
(13.2 \%)\end{array}$ & $\begin{array}{l}1133 \\
(56.7 \%)\end{array}$ & - & $\begin{array}{l}261 \\
(13.1 \%)\end{array}$ & $\begin{array}{l}343 \\
(17.2 \%)\end{array}$ \\
\hline 9 & $\begin{array}{l}\text { Nigeria Police respond to my call and take immediate } \\
\text { action when the need arises }\end{array}$ & $\begin{array}{l}343 \\
(17.2 \%)\end{array}$ & $\begin{array}{l}871 \\
(43.6 \%)\end{array}$ & - & $\begin{array}{l}322 \\
(16.1 \%)\end{array}$ & $\begin{array}{l}464 \\
(23.2 \%)\end{array}$ \\
\hline 10 & $\begin{array}{l}\text { Policemen have all the needed knowledge to help their } \\
\text { clients }\end{array}$ & $\begin{array}{l}133 \\
(6.7 \%)\end{array}$ & $\begin{array}{l}1187 \\
(59.4 \%)\end{array}$ & - & $\begin{array}{l}204 \\
(10.2 \%)\end{array}$ & $\begin{array}{l}476 \\
(23.8 \%)\end{array}$ \\
\hline
\end{tabular}


British Journal of Marketing Studies (BJMS)

Vol. 8, Issue 1, pp.29-46, February 2020

Published by ECRTD- UK

Print ISSN: 2053-4043(Print), Online ISSN: 2053-4051(Online)

\begin{tabular}{|c|c|c|c|c|c|c|}
\hline 11 & Policemen behavior instill confidence in me & $\begin{array}{l}220 \\
(11 \%)\end{array}$ & $\begin{array}{l}992 \\
(49.6 \%)\end{array}$ & - & $\begin{array}{l}358 \\
(17.9 \%)\end{array}$ & $\begin{array}{l}430 \\
(21.5 \%)\end{array}$ \\
\hline 12 & $\begin{array}{l}\text { Policemen will provide adequate security to protect me } \\
\text { whenever the need arise }\end{array}$ & $\begin{array}{l}352 \\
(17.6 \%)\end{array}$ & $\begin{array}{l}872 \\
(43.6 \%)\end{array}$ & - & $\begin{array}{l}300 \\
(15 \%)\end{array}$ & $\begin{array}{l}476 \\
(23.8 \%)\end{array}$ \\
\hline 13 & Policemen provide services that best suit my needs & $\begin{array}{l}313 \\
(15.7 \%)\end{array}$ & $\begin{array}{l}1151 \\
(57.6 \%)\end{array}$ & - & $\begin{array}{l}184 \\
(9.2 \%)\end{array}$ & $\begin{array}{l}352 \\
(17.6 \%)\end{array}$ \\
\hline 14 & Policemen have my interest at heart & $\begin{array}{l}312 \\
(15.6 \%)\end{array}$ & $\begin{array}{l}921 \\
(46.1 \%)\end{array}$ & - & $\begin{array}{l}427 \\
(21.4 \%)\end{array}$ & $\begin{array}{l}340 \\
(17 \%)\end{array}$ \\
\hline 15 & Policemen give me individual attention & $\begin{array}{l}366 \\
(18.3 \%)\end{array}$ & $\begin{array}{l}897 \\
(44.9 \%)\end{array}$ & - & $\begin{array}{l}326 \\
(16.3 \%)\end{array}$ & $\begin{array}{l}411 \\
(20.6 \%)\end{array}$ \\
\hline
\end{tabular}

Source: Researcher's Field Survey, 2019

In Table 04, 275(13.8\%) of the respondent strongly disagreed that police station physical facilities (e.g. building and furniture's) are virtually nice, 1118(55.9\%) disagreed while 145(7.3\%) agreed and $462(23.1 \%)$ strongly agreed. 295(14.8\%) strongly disagreed that police are neatly appealing in their uniform, $729(36.5 \%)$ disagreed while $274(13.7 \%)$ agreed and $702(35.1 \%)$ strongly agreed. $392(19.6 \%)$ strongly disagreed that technology and equipment are up-to-date, 973(48.7\%) disagreed while 291(14.6\%) agreed and 344(17.2\%) strongly agreed. 368(18.4\%) strongly disagreed that Police provide all the services as promised, 1174(58.7\%) disagreed while 184(9.2\%) agree and 274(13.7\%) strongly agreed. 225(11.3\%) strongly disagreed that policemen operating hours are convenient to them, 981(49.1\%) disagreed while 314(15.7\%) agreed and 480(24\%) strongly agreed.

Similarly, 336(16.8\%) strongly disagreed that the Nigerian Police force deliver error free and up to date services, $818(40.9 \%$ ) disagreed while 339(17\%) agreed and 507(25.4\%) strongly agreed. $171(8.6 \%)$ strongly disagreed that police are willing to help them whenever the need arise, $1090(54.5 \%)$ disagreed while 223(11.2\%) agreed and 516(25.6\%) strongly agreed. 263(13.2\%) strongly disagreed that The Nigeria police force provide quick services in solving client's problems, 1133(56.7\%) disagreed, while 261(13.1\%) agreed and 343 (17.2\%) strongly agreed. $343(17.2 \%)$ strongly disagreed that Nigeria Police respond to call and take immediate action when the need arises, 871(43.6\%) disagreed while 322(16.1\%) agreed and 464 (23.2\%) strongly agreed. A total of $133(6.7 \%)$ strongly disagreed that Policemen have all the needed knowledge to help their clients, 1187(59.4\%) disagreed while 204(10.2\%) agreed and 476 (23.8\%) strongly agreed. $220(11 \%)$ strongly disagreed that policemen behavior instill confidence in them, 992(49.6\%) disagreed while 358(17.9\%) agreed and 430(21.5\%) strongly agreed. 352(17.6\%) strongly disagreed that policemen will provide adequate security to protect me whenever the need arise, $872(43.6 \%)$ disagreed while 300(15\%) agreed and 476(23.8\%) strongly agreed. 313(15.7\%) strongly disagreed that policemen provide services that best suit their needs, $1151(57.6 \%)$ disagreed while 184(9.2\%) agreed and 352(17.6\%) strongly agreed. 312(15.6\%) strongly disagreed that policemen have their interest at heart, 921(46.1\%) disagreed while 427(21.4\%) agreed and 340(17\%) strongly agreed. Similarly, 366(18.3\%) strongly disagreed that policemen give them individual attention, 897(44.9\%) disagreed while 326(16.3\%) agreed and 411(20.6\%) 
British Journal of Marketing Studies (BJMS)

Vol. 8, Issue 1, pp.29-46, February 2020

Published by ECRTD- UK

Print ISSN: 2053-4043(Print), Online ISSN: 2053-4051(Online)

strongly agreed.

Table 05: Awareness of SERVICOM in the Nigeria Police Force

\begin{tabular}{|c|c|c|c|}
\hline $\mathbf{S} / \mathbf{N}$ & ITEMS & YES & NO \\
\hline 1 & Are you aware of SERVICOM in the Nigeria Police Force? & $167(8.4 \%)$ & $1833(91.7 \%)$ \\
\hline 2 & $\begin{array}{l}\text { Do you think the Nigerian Police deliver their services in } \\
\text { accordance with SERVICOM dictate? }\end{array}$ & $708(35.4 \%)$ & $1292(64.6 \%)$ \\
\hline 3 & $\begin{array}{l}\text { Are there factors you think militate against the full implementation } \\
\text { of SERVICOM in the Nigeria Police force? }\end{array}$ & $1596(79.8 \%)$ & $404(20.2 \%)$ \\
\hline 4 & $\begin{array}{l}\text { Do you think introduction of SERVICOM can enhance Nigeria } \\
\text { Police service delivery if religiously followed }\end{array}$ & $1612(80.6 \%)$ & $388(19.4 \%)$ \\
\hline 5 & $\begin{array}{l}\text { Are there improvements in the service delivery of the NPF since the } \\
\text { introduction of SERVICOM }\end{array}$ & $1304(65.2 \%)$ & $696(34.8 \%)$ \\
\hline 6 & $\begin{array}{l}\text { Are there available equipment adequate for the NPF to perform } \\
\text { their services according to SERVICOM dictate? }\end{array}$ & $1799(90 \%)$ & $201(10 \%)$ \\
\hline 7 & $\begin{array}{l}\text { Do you think the NPF receive up-to-date training to be able to meet } \\
\text { the demand of SERVICOM? }\end{array}$ & $\begin{array}{l}1526 \\
(76.3 \%)\end{array}$ & $474(23.7 \%)$ \\
\hline 8 & $\begin{array}{l}\text { Does the working environment motivate Nigeria Police Officers to } \\
\text { positively contribute their best according to the requirement of } \\
\text { SERVICOM? }\end{array}$ & $\begin{array}{l}1685 \\
(84.3 \%)\end{array}$ & $315(15.8 \%)$ \\
\hline 9 & $\begin{array}{l}\text { Do you think the promotion of NPF personnel is regular to } \\
\text { encourage them to put in their best according to SERVICOM } \\
\text { dictate? }\end{array}$ & $1620(81 \%)$ & $380(19 \%)$ \\
\hline 10 & $\begin{array}{l}\text { Is the current salary and allowances received by Nigeria Police } \\
\text { Officers sufficient to motivate them to optimum performance? }\end{array}$ & $\begin{array}{l}1964 \\
(98.2 \%)\end{array}$ & $36(1.8 \%)$ \\
\hline 11 & $\begin{array}{l}\text { Does the establishment of other security agencies (e.g. Civil } \\
\text { Defence, Peace corps, e.t.c.) adequately compliment the NPF } \\
\text { toward the attainment of SERVICOM goals? }\end{array}$ & $\begin{array}{l}1375 \\
(68.8 \%)\end{array}$ & $625(31.3 \%)$ \\
\hline 12 & $\begin{array}{l}\text { Do you think the available infrastructural facilities (e.g. road, } \\
\text { electricity, e.t.c.) across the length and breadth of the country assist } \\
\text { the NPF in rendering quick service delivery? }\end{array}$ & $\begin{array}{l}1812 \\
(90.6 \%)\end{array}$ & $188(9.4 \%)$ \\
\hline 13 & $\begin{array}{l}\text { Do you think the Nigerian populace assists the NPF by providing } \\
\text { information that could lead to better service delivery? }\end{array}$ & $\begin{array}{l}1123 \\
(56.2 \%)\end{array}$ & $877(43.9 \%)$ \\
\hline 14 & $\begin{array}{l}\text { Do you think the insurance policy programme of the government } \\
\text { for the NPF is adequate to make them go extra mile in the pursuit } \\
\text { of SERVICOM objectives? }\end{array}$ & $\begin{array}{l}1367 \\
(68.4 \%)\end{array}$ & $633(31.7 \%)$ \\
\hline 15 & $\begin{array}{l}\text { Do you think the NPF housing schemes offers you comfortable/ } \\
\text { conducive accommodation that is commensurate with your rank? }\end{array}$ & $\begin{array}{l}1711 \\
(85.6 \%)\end{array}$ & $289(14.5 \%)$ \\
\hline
\end{tabular}

Source: Researcher's Field Survey, 2019 
British Journal of Marketing Studies (BJMS)

Vol. 8, Issue 1, pp.29-46, February 2020

Published by ECRTD- UK

Print ISSN: 2053-4043(Print), Online ISSN: 2053-4051(Online)

Table 05 reveals that $167(8.4 \%)$ of the total respondents agreed that they are aware of SERVICOM in the Nigeria Police Force while 1833(91.7\%) disagreed. 708(35.4\%) agreed that Nigeria Police deliver their services in accordance with SERVICOM dictate while 1292(64.6\%) disagreed. $1596(79.8 \%)$ agreed that there are factors militating against the full implementation of SERVICOM in the Nigeria Police Force while 404(20.2\%) disagreed. 1304(65.2\%) agreed that there are improvements in the service delivery of the NPF since the introduction of SERVICOM while 696(34.8\%) disagreed. Furthermore, 1799(90\%) agreed that adequate equipment are available for the NPF to perform their services according to SERVICOM dictate while 201(10\%) disagreed. 1526(76.3\%) agreed that NPF received up-to-date training to be able to meet the demand of SERVICOM, 474(23.7\%) disagreed. 1685(84.3\%) agreed that the working environment motivate Nigeria Police Officers to positively contribute their best according to the requirement of SERVICOM while 315(15.8\%) disagreed.

$1620(81 \%)$ agreed that the promotion of NPF personnel is regular to encourage them to put in their best according to SERVICOM dictate while 380(19\%) disagreed. 1964(98.2\%) agreed that the current salary and allowances received by Nigeria Police Officers is sufficient to motivate them to optimum performance while $36(1.8 \%$ ) disagreed. $1375(68.8 \%)$ agreed that the establishment of other security agencies (e.g. civil defence, peace corps, e.t.c.) adequately compliment the NPF toward the attainment of SERVICOM goals while 625(31.3\%) disagreed. 1812(90.6\%) agreed that the available infrastructural facilities (e.g. road, electricity, e.t.c.) across the length and breadth of the country assist the NPF in rendering quick service delivery while 188(9.4\%). Similarly, $1123(56.2 \%)$ agreed that the Nigerian populace assists the NPF by providing information that could lead to better service delivery while $877(43.9 \%)$ disagreed. 1367(68.4\%) agreed that the insurance policy programme of the government for the NPF is adequate to make them go extra mile in the pursuit of SERVICOM objectives, 633(31.7\%) disagreed. 1711(85.6\%) agreed that the NPF housing schemes offers comfortable/conducive accommodation that commensurate with rank, 289(14.5\%) disagreed.

\section{RESULTS AND DISCUSSIONS}

\section{Hypothesis 1}

There is no significant effect of professionalism of services on the Nigeria Police Force service delivery.

Table 06: t-test showing the effect of professionalism of service and service delivery

\begin{tabular}{llllll}
\hline Variables & $\boldsymbol{N}$ & Mean & $\boldsymbol{S D}$ & $\boldsymbol{t}$ & $\boldsymbol{P}$ \\
\hline Professionalism & 2000 & 18.37 & 4.63 & $3.879^{*}$ & 0.000 \\
Service Delivery & 2000 & 17.96 & 2.96 & &
\end{tabular}

\section{$* \mathbf{p}<0.05$}

Table 06 shows that there is significant effect of professionalism of service on the Nigeria Police Force Service delivery $(\mathrm{t}=3.879, \mathrm{p}<0.05)$. The null hypothesis is rejected. This implies that there 
British Journal of Marketing Studies (BJMS)

Vol. 8, Issue 1, pp.29-46, February 2020

Published by ECRTD- UK

Print ISSN: 2053-4043(Print), Online ISSN: 2053-4051(Online)

is significant effect of professionalism of service on the Nigeria Police Force Service delivery. This showed that if professionalism is given adequate consideration in the Nigeria Police Force, it would definitely enhance their service delivery.

\section{Hypothesis 2}

There is no significant difference between customers' expectation and perception regarding the quality of service provided by the Nigeria Police Force.

Table 07: Chi-square $\left(\chi^{2}\right)$ of customers' expectation and perception regarding the quality of service provided by the Nigeria Police Force

\begin{tabular}{|c|c|c|c|c|c|c|c|c|}
\hline \multirow{2}{*}{$\begin{array}{ll}\text { Dimensions } & \text { of } \\
\text { service quality } & \end{array}$} & \multicolumn{6}{|c|}{ Responses } & \multirow[t]{3}{*}{$\chi^{2}$} & \multirow{3}{*}{$\mathbf{p}$} \\
\hline & SD & $\mathbf{D}$ & $\mathbf{A}$ & SA & Total & \multirow[t]{2}{*}{ df } & & \\
\hline Tangibles & $\begin{array}{l}285 \\
(14.2 \%)\end{array}$ & $\begin{array}{l}924 \\
(46.2 \%)\end{array}$ & $\begin{array}{l}210 \\
(10.5 \%)\end{array}$ & $\begin{array}{l}582 \\
(29.1 \%)\end{array}$ & $\begin{array}{l}2001 \\
(100.0 \%)\end{array}$ & & & \\
\hline Reliability & $\begin{array}{l}310 \\
(24.1 \%)\end{array}$ & $\begin{array}{l}279 \\
(21.7 \%)\end{array}$ & $\begin{array}{l}279 \\
(21.7 \%)\end{array}$ & $\begin{array}{l}420 \\
(32.6 \%)\end{array}$ & $\begin{array}{l}1288 \\
(100.0 \%)\end{array}$ & \multirow{5}{*}{12} & \multirow{5}{*}{$m$} & \multirow{5}{*}{\begin{tabular}{l}
8 \\
8 \\
\hdashline
\end{tabular}} \\
\hline Responsiveness & $\begin{array}{l}259 \\
(9.6 \%)\end{array}$ & $\begin{array}{l}1031 \\
(38.0 \%)\end{array}$ & $\begin{array}{l}269 \\
(9.9 \%)\end{array}$ & $\begin{array}{l}1153 \\
(42.5 \%)\end{array}$ & $\begin{array}{l}2712 \\
(100.0 \%)\end{array}$ & & & \\
\hline Assurance & $\begin{array}{l}235 \\
(11.8 \%)\end{array}$ & $\begin{array}{l}1017 \\
(50.9 \%)\end{array}$ & $\begin{array}{l}287 \\
(14.4)\end{array}$ & $\begin{array}{l}461 \\
(23.1 \%)\end{array}$ & $\begin{array}{l}2000 \\
(100.0 \%)\end{array}$ & & & \\
\hline Empathy & $\begin{array}{l}330 \\
(16.5 \%)\end{array}$ & $\begin{array}{l}990 \\
(49.5 \%)\end{array}$ & $\begin{array}{l}312 \\
(15.6 \%)\end{array}$ & $\begin{array}{l}367 \\
(18.4 \%)\end{array}$ & $\begin{array}{l}1999 \\
(100.0 \%)\end{array}$ & & & \\
\hline Total & $\begin{array}{l}1419 \\
(14.2 \%)\end{array}$ & $\begin{array}{l}4241 \\
(42.4 \%)\end{array}$ & $\begin{array}{l}1357 \\
(13.6 \%)\end{array}$ & $\begin{array}{l}2983 \\
(29.8 \%)\end{array}$ & $\begin{array}{l}1000 \\
(100.0 \%)\end{array}$ & & & \\
\hline
\end{tabular}

$\bar{p} \mathbf{p}<0.05$

Table 07 reveals that there is significant difference between customers' expectation and perception regarding the quality of service provided by the Nigeria Police Force $\left(\chi^{2}=731.651, p<0.05\right)$. The null hypothesis is rejected.

\section{CONCLUSIONS AND RECOMMENDATIONS}

In view of the findings of this study, the following conclusions are made:

There is significant effect of professionalism of service on the Nigeria Police Force Service delivery. This shows that if effective service must be provided by any service organization, there is need to deliver such service using the service benchmark for the industry. It therefore connotes that any service delivery that falls short of the industry benchmark will not be acceptable. In order to meet the requirement of service in the NPF, professionalism must be considered very important. 
Print ISSN: 2053-4043(Print), Online ISSN: 2053-4051(Online)

More so, there is significant difference between customers' expectation and perception regarding the quality of service provided by the Nigeria Police Force. This is a proof that Nigerians who the police are expected to serve are not too satisfied with the quality of service they receive from the NPF. It is glaring that their expectations are not met either before service encounter, at the point of service and post service encounter. This singular act could breach the trust of people on the NPF and the consequence could result in self defence or reliance on alternative means of security.

Consequent upon the findings and conclusion of this study, the following recommendations are very germane:

i. Since professionalism demands application of the best practices to do a task, there is need for authority of the NPF and other regulatory authorities to ensure regular training of officers both within and outside the country. These training programmes will afford NP officers to learn new skills about the profession that will put them on the same pedestal with their counterparts in other parts of the world.

ii. This study shows that there is gap between customers' expectation and perception of service. On this basis of this, there is need for holistic action to be taken to overhaul every aspect of the service provided by the NPF. Firstly, the service should be made faster by providing facility and equipment capable of responding promptly to the scene of crime.

iii. Secondly, there is need to rebrand the NPF because the agency image is currently battered in the public. They are still seen as enemies' inspite of the slogan that NP are your friends. People with questionable integrity should not be employed into the NPF and those who are currently in should be re-orientated or dismissed.

iv. There should be public sensitization for members of the public to provide vital information to assist the NPF to do their jobs better. This is important because criminals live in the midst of the people and if NP officers are not privy to information, identifying them may be difficult.

v. Policy makers in government and regulatory authorities in the Nigerian Police Force should take steps to ensure that the operations of the Nigerian Police Force are consistent with the variations in SERVICOM in order to ensure that its implications on professionalism of service delivered by the Nigerian Police Force is consistent with the general goals of SERVICOM.

vi. Regulatory authorities in the Nigerian Police Force should take steps to ensure that the operations of the Nigerian Police Force are, to some extent, consistent with the expectations of customers. This will help to minimize the discrepancies between customers' expectation of services from the Nigerian Police Force and the actual service realized from the Force. One of the ways to achieve this is through improved Police public relations and adequate feedback and feed forward mechanisms.

\section{References}

1. Adebayo, P. F. and Ojo, E. O. (2009). "The Challenges of Effective Policing as Measure of Controlling the Phenomenon of Police Corruption in Nigeria Today", International NGO Journal, 4 (3), 70-75. 
British Journal of Marketing Studies (BJMS)

Vol. 8, Issue 1, pp.29-46, February 2020

Published by ECRTD- UK

Print ISSN: 2053-4043(Print), Online ISSN: 2053-4051(Online)

2. Atijosan, J. I. (2010). “Marketing Research”, Akure, Boluwatife Press and Publishing (Nig) Limited.

3. Balogun, A. T. (2002). Crime Control Strategy "Eight-Point Strategies" of the Nigerian Police Force Programme Action, To serve and to Protect with Integrity, Minna, Yalian Press Ltd

4. Boyt, T. E., Lusch, R. F. and Naylor, G. (2001). "The Role of Professionalism in Determining Job Satisfaction in Professional Services, A Study of Marketing Reasearches". Journal of Service Research, 3 (4), 321-330.

5. Englund, T. (1996). Are Professional Teachers a Good Thing? In Goodson, I. and Hargreaves, A. (eds) Teachers' Professional Lives (London, Falmer).

6. Evetts, J. (2006). Introduction, Trust and Professionalism, Challenges and Occupational Changes, Current Sociology, 54 (4), 515-531.

7. Fox, C. J. (1992). What do we Mean when we Say Professionalism? A Language Usage Analysis for Public Administration. The American Review of Public Administration, 22 (1), 1-17.

8. Freidson, E. (1994). Professionalism Reborn, Theory, Prophecy and Policy (Cambridge, Polity press, In association with Blackwell Publishers).

9. Glesson, D., Davies, J. and wheeler, E. (2005). On the Making and Taking of Professionalism in the Further Education Workplace. British Journal of Sociology of Education, 26 (4), 445-460.

10. Global Security (1983). Buhari Coup. Http;//www.globalsecurityorg/military/world/war/ Nigeria2.htm.

11. Hargreaves, A. and Goodson, I. (1996). Teachers' Professional Lives, Aspirations and Actualities. In I. Goodson and A. Hargreaves (eds). Teachers' Professional lives (London, Falmer).

12. Helsby, G. (1995). Teachers' Constrction of Professionalism in England in the 1990s, Journal of Education for Teaching, 21 (3), 317-332.

13. Helsby, G. (1999). Multiple Truths and Contested Realities, The Changing Faces of Teacher Professionalism in England. In Day, C., Fernandez, A., Hague, T. and Moller, J. (eds). The Life and Work of Teachers (London, Falmer).

14. Holroyd, C. (2000). Are Assessors Professional? Active Learning in Higher Education, $1(1), 28-44$.

15. Hoyle, E. (1975). Professionality, Professionalism and Control in Teaching. In Houghton V. et al. (eds). Management in Education, The Management of Organizations and Individuals (London, Ward Lock Educational in Association with Open University Press).

16. Hoyle, E. (2011). Teaching, Prestige, Status and Esteem. Educational Management and Administration, 29 (2), 139-152.

17. Osayande, B. O. (2008). "Factors Inhibiting Police Performance in Nigeria", A Paper Presented at the Occasion of the Retreat with the Theme; "Understanding the Mandate and Operations of the Police Service Commission in the Context of the Rule of Law"

18. Ozga, J. (1995). Deskilling a Profession. Professionalism, Deprofessionalisation and the new Managerialism. In Busher, H. and Saran, R. (eds). Managing Teachers as Professionals in Schools (London, Kogan Page). 
British Journal of Marketing Studies (BJMS)

Vol. 8, Issue 1, pp.29-46, February 2020

Published by ECRTD- UK

Print ISSN: 2053-4043(Print), Online ISSN: 2053-4051(Online)

19. Tinubu, K. (1993). "Future Police Statutory Function and Power in Policing Nigeria, Past, Present and Future" In Tekena, N. T. (ed) Lagos, Malthouse Press.

20. Troman, G. (1996). The Rise of the new Professionals? The Restructuring of Primary Teachers' Work and Professionalism, British Journal of Sociology of Education, 17 (4), $473-487$.

21. Sachs, J. (1999). Rethinking the Practise of Teacher Professionalism. In C. day, A. Fernandez, T. hague and J. Moller (eds). The Life and Work of Teachers (London, Falmer).

22. Sockett, H. T. (1996). Teachers for the $21^{\text {st }}$ Century, Redefining Professionalism, NASSP Bulletin, May, 1996, 22-29.

23. Weber, M. (1968). Economy and Society, USA, University of California Press.

24. Yecho, J. I. (2004). "Policing Crime or Status?, A Review of Police Law Enforcement Practice in Nigeria" In Journal of Sociology and Anthropology Students, BSU, Makurdi.

\section{Acknowledgements}

The Management of Federal Polytechnic, Ado-Ekiti is well appreciated for the permission granted in carrying out this research work. Also, the contribution of TETFUND is highly commendable for providing an enabling environment in terms of finance to carry out this research work. If not for the opportunity enjoyed from TETFUND, this research work would have been a mirage. 